\title{
ETHNICITY, DEVELOPMENT, CRIMES AND CONFLICT IN A MULTI-ETHNIC URBAN SETTING IN MALAYSIA: TRANS-BORDER SOCIOLOGICAL AND GIS ANALYSES OF AN URBAN SOCIETY
}

\author{
MANSOR MOHD NOOR ${ }^{1} \&$ NUR SUHAILI MANSOR ${ }^{2}$ \\ ${ }^{1}$ Universiti Kebangsaan Malaysia \\ ${ }^{2}$ Universiti Utara Malaysia
}

\begin{abstract}
Sociologists have often worked in silo from other disciplines in their attempts to observe and explain the social phenomenon being studied. This research project is based on the need to combine a social science approach to studying social phenomenon with inputs from science and technology. In this study, data on development and its relationship with crimes and conflict in a multi ethnic urban setting are collected based on a social survey, narcotic data from the police records, and Geographic Information System (GIS) of the development of the township Sungai Petani. The social survey does indicate that development taking place is socially structured in which the Chinese community avails themselves to the fruits of urban development relative to Malays and Indians. The longitudinal data of urban development from GIS indicates that as development and urban areas expand, the Malays in the rural areas and Indians living on the rubber estates are dislocated and join the urban pours with low education and job skills. The narcotic data collected were superimposed on the longitudinal GIS data of Sungai Petani. The patterns of narcotic related crime are observed to have a relationship with the expansion of industrial and housing schemes. In an urban multi-ethnic setting such as Malaysia, development, social inequality and crime if not identify and manage, often end in ethnic conflict. This township has shown such social ruptures in 2012 when these ethnic groups of development losers, street bikers and gangsters fought across ethnic lines and produce a spiralling downward trend of good ethnic relations that had been enjoyed before this incident in this town.
\end{abstract}

Keywords: ethnicity, ethnic relations, crime, conflict, urban growth, development.

\section{INTRODUCTION}

The world capitalist system induced-development taking place on a global scale spurs by the digital platform has not only brought progress and societal well-being to most nations but also some contradiction in its path [1]. The faster the economic growth rate the greater would it be the gap social inequality between the rich and poor and the marginalisation of the voiceless and powerful produce a generation of a precariat class in the society. Such failures of development would add salt to the wound in a post-colonial plural society as Malaysia.

Ethnic differences may not be the cause but often poverty and intergenerational marginalisation in a plural society are breeding ground of ethnic mobilisation in the face of bad governance and development failures.

\section{LOCATING THE MULTI-ETHNIC NATION}

Post-colonial plural society of Malaysia is a product of British colonialism in which a promigration policy was depended on to bring in Chinese labourers to man the tin-mining and the commercial activities in the urban areas and the Indians to be rubber tappers on the estate [2]. The indigenous population of the Malays were left to fish and produce rice. In 1930, the population of the migrant communities has exceeded the local population [3]. As the nation moved towards independence in 1957, giving citizenship, educational position to mother tongue languages and cultural practices are differences between the political interests of the 
Malays via-a-via of the Chinese and the Indian communities [4]. As integration is the basis of nation-building, the Federal Constitution promulgated is the platform in which indigeneity and diversity are the foundation of the nation.

Ethnic groups in Malaysia are defined by the parameters of language, culture and religion. Thus, Malaysian ethnic groups are defined along these parameters. There are over 200 ethnic groups in Malaysia [5]. In 2017 the population was 31 million people. The distribution by ethnic groups, the Malay $50.1 \%$, Chinese $22.6 \%$, indigenous $11.8 \%$, Indian $6.7 \%$, other $0.7 \%$, non-citizens $8.2 \%$ [6].

Huntington defines human progress as a movement toward economic development, material well-being and political democracy. Seers locates development as fulfilling needbased. But later Seers also see the concept of development was linked to developing the human individual potential, Today, Seers added 2 other elements; independence, the rise of independence - self cultural empowerment. Human empowerment becomes the ultimate aim of development. Even Sen argues that development as the basis of freedom of man [7].

As Malaysia gives priorities to the Millennial Development Goals in its development policy, the post-1970s saw a high rate of development that transforms the subsistence farming into and industrial, populated by the poor to a middle class and a rural life to a cosmopolitan tied to capitalism, globalisation and the cyber world.

East Asia's Changing Urban Landscape: Measuring a Decade of Spatial Growth [8], Malaysia is among the more urbanized countries of East Asia, and its urban population continues to increase rapidly. Its urban population increased during this period from 10.2 million ( $43 \%$ of the total population) to 15 million (53\%), making it among the more urbanized countries and economies in the region in demographic terms, after Japan, the Republic of Korea, and Singapore (and Taiwan, China).

Development and urbanisation has brought not only social changes but also social transformation of the post-colonial society into a diverse society in which ethnic boundary prevails but their social actions are motivated by the concerns of material, status and personal obligation rather than the calculation of ethnic preference. Thus, as sharing of norms are observed among the diverse ethnic population, cross-cutting social ties and relationship are the dominant pattern in the society rather than their ethnicities [9].

In a post-colonial society, ethnic competition over societal resources and social esteem could heighten social tension and, inevitably, ending in ethnic riots. Malaysia has its ethnic fights and riots, the bloodiest taking place in 1969 [10]. However, since 1970s Malaysia experience a long spate of ethnic harmony and peace in the country. Toward the end of the 1990s, growing social inequality saw a number of ethnic skirmishes in Kampung Rawa, Kampung Medan, Lawas and Sungai Petani as well as street demonstrations of Bersih, the Red Shirt, the incidents at Low Yatt and Plaza Kota Raya in Kuala Lumpur create tense situations in the nation [11], [12].

The feeling of ethnic risks is felt greater during election time as over-zealot politicians exploited ethnic and religious differences in order to gain vote to secure their political seats. However, the ethnic tension often clears the diverse society in three months as the sane society that share greater similarity rather than difference to prevails over the ethnic and religious demagoguery.

\section{THE SOCIAL CONFLICT IN THE TOWN OF SUNGAI PETANI, KEDAH, MALAYSIA}

In the morning of the 16th December 2012, fighting broke out between the Indian dan Malay youths in the town of Sungai Petani, Kedah, Malaysia. No lost of life was reported but a number of Indian and Malay youths were injured. However, the social media-based the 
digital platform of the internet and the smart phone were viralling information that ethnic riots were taking place there. The Police immediately defused the tense social situation by releasing press statement that the town is peaceful and safe [13].

\section{METHODOLOGY}

This study is located in the town of Sungai Petani and in the southern part of the State of Kedah in the North of Peninsular Malaysia. This town is about 70KM away from Alor Setar, the state capital of Kedah, and closer to the industrial zone of Penang by 10KM. Sungai Petani is benefitting from the industrial development in Penang and the overspills there has also generated this town into an industrial city and as the largest town in State of Kedah.

Fig. 1 explains the result of classification for urban growth in Sungai Petani, Kedah. These growths took place during a 13-year span from 2000 to 2013. The red color shows urban growth within the year.

The immediate impacts of these urban growth saw the emergence of new housing schemes, new township, industrial zone and new commercial satellite in Sungai Petani. Those who have gained good education, job and income reap benefits from the industrialisation and urbanisation taking place. Those groups that once have resided in these developing areas were driven out of the rural population and the agriculture work force to the urban areas. Those who have sufficient levels of education and skills were able to work as the industrial workforce and labourers in the business opening in the township. However, the lowly educated and unskilled labourers of this group joined the indigent poor of the urban areas [14].

This research is based on a trans-border disciplines of the social sciences and sciences. This study exploits the strengthen of sociology and its branches of development, ethnic relations, criminology and urban study as well as the discipline of geographical information system from the science and technology.

The research designs are quantitative in collected data on the social data and GIS data of the changing patterns of land used in the study area of Sungai Petani, Kedah.

The primer data on crimes are collected from the register of crimes of the Royal Malaysian Police, Sungai Petani, Kedah. The GIS data was obtained from the Department of Urban and Rural Areas and the Local Authority of Sungai Petani, Kedah. While the data for the social

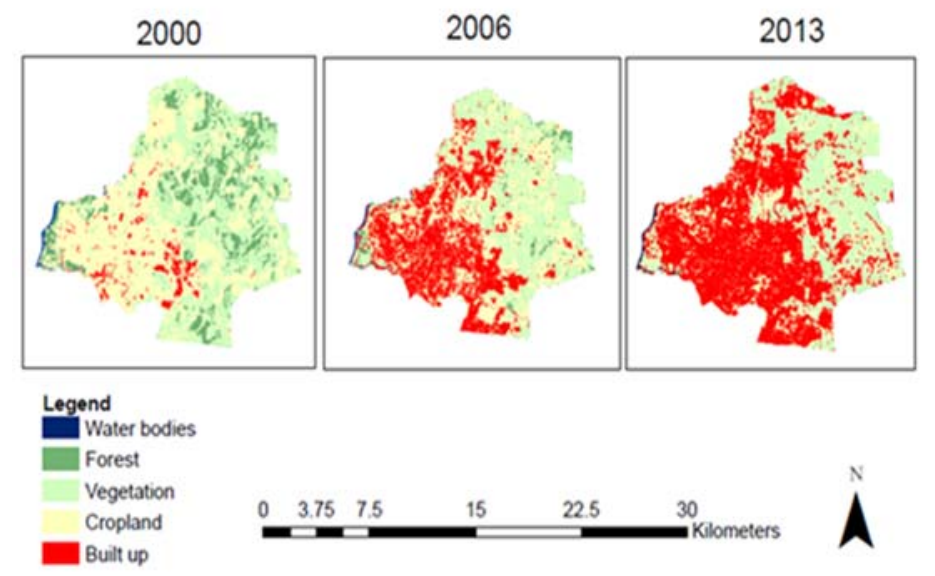

Figure 1: Urban growth in Sungai Petani from year 2000, 2006 and 2013. 
survey, a total 444 respondents were interviewed and ethnically distributed with Malays $49 \%$, Indians $32 \%$ and Chinese $18 \%$. These respondents were selected from five housing schemes in the town of Sungai Petani, viz, 1. Taman Ria Jaya, 2. Taman Keladi, 3. Taman Ria, Flat Paya Nahu, 4. Flat Paya Nahu 1 dan 5. Taman Petani Jaya.

\section{THE RESULTS}

\subsection{Correlation between crime and urban growth}

Urban growth is one of the most critical types of worldwide change, and most urban areas are experiencing increased growth in population and infrastructure development. Increases in urbanization lead to many changes in the daily activities of people living within an affected area. Urban growth, over time, can also change the potential for crime [15]. Usually, people are attracted to large cities because they are social and economic centers; however, this makes them more opportune places for crime to occur. Crime is an intricate issue, and many researchers have concurred that a connection between crime and land use exists [16]. Theories about opportunity for crime suggest that crime and population are related; where there is a density of crime, there is a density of population [17]. Below are the results for the study area.

Table 1: Spearman's rank order correlation test result for overall crime.

\begin{tabular}{|l|l|c|c|}
\hline \multicolumn{2}{|c|}{} & Urban Growth & Crime \\
\hline \multirow{4}{*}{ Urban Growth } & Correlation Coefficient & 1.000 & .059 \\
\cline { 2 - 4 } & Sig. (2-tailed) &. & .840 \\
\cline { 2 - 4 } & $\mathrm{N}$ & 14 & 14 \\
\hline \multirow{3}{*}{ Crime } & Correlation Coefficient & .059 & 1.000 \\
\cline { 2 - 4 } & Sig. (2-tailed) & .840 &. \\
\cline { 2 - 4 } & $\mathrm{N}$ & 14 & 14 \\
\hline
\end{tabular}

Table 2: Spearman's rank order correlation test result for violence crime.

\begin{tabular}{|l|l|c|c|}
\hline \multicolumn{2}{|l|}{} & Urban Growth & Violence Crime \\
\hline \multirow{3}{*}{ Urban Growth } & Correlation Coefficient & 1.000 & $.833^{* *}$ \\
\cline { 2 - 4 } & Sig. (2-tailed) &. & .000 \\
\cline { 2 - 4 } & $\mathrm{N}$ & 14 & 14 \\
\hline Violence Crime & Correlation Coefficient & $.833^{* *}$ & 1.000 \\
\cline { 2 - 4 } & Sig. (2-tailed) & .000 & $\cdot$ \\
\cline { 2 - 4 } & $\mathrm{N}$ & 14 & 14 \\
\hline Significance & $* *$ Correlation is significant at the 0.01 level (two-tailed) \\
\hline
\end{tabular}


5.1.1 Growth vs crime (overall)

When Spearman's rank-order correlation approach was run to test the relationship between overall crime and urban land, the preliminary data assessed by the visual inspection of a scatterplot showed that the relationship was not exactly monotonic. Although the linear equation shows that there is a small positive relationship, the correlation was not strong $(\mathrm{r}=$ $0.059, \mathrm{p}>0.05)$ and we can say that there was no significant correlation.

\subsubsection{Urban growth vs violence crime}

In testing the relationship between Violence Crime and urban Growth in Sungai Petani, the Spearman correlation coefficient suggests a positive correlation $(=0.833)$. An increase in overall crime during the period was strongly associated with an increase in urban area (rs (8) $=0.833, \mathrm{p}<0.05)$.

\subsubsection{Urban growth vs property crime}

There was no significant correlation between these two. The correlation coefficient was negative; it was -0.495 with a p-value of 0.072 , where it exceeded 0.05 . Thus, there was no significant correlation between property crime and urban expansion in the Sungai Petani town.

5.1.4 Urban growth vs drug abuse

A Spearman's rank-order correlation was run to assess the relationship between urban change over the period of time and crime rate in Sungai Petani. There was a positive correlation between urban expansion and drug abuse $(\mathrm{rs}(8)=0.587, \mathrm{p}<0.05)$.

Table 3: Spearman's rank order correlation test result for Property Crime.

\begin{tabular}{|l|l|c|c|}
\hline \multicolumn{2}{|c|}{} & Urban Growth & Property Crime \\
\hline \multirow{4}{*}{ Urban Growth } & Correlation Coefficient & 1.000 & -.495 \\
\cline { 2 - 4 } & Sig. (2-tailed) &. & .072 \\
\cline { 2 - 4 } & $\mathrm{N}$ & 14 & 14 \\
\hline \multirow{2}{*}{$\begin{array}{l}\text { Property } \\
\text { Crime }\end{array}$} & Correlation Coefficient & -.495 & 1.000 \\
\cline { 2 - 4 } & Sig. (2-tailed) & .072 &. \\
\cline { 2 - 4 } & $\mathrm{N}$ & 14 & 14 \\
\hline
\end{tabular}

Table 4: Spearman's rank order correlation test result for Property Crime.

\begin{tabular}{|l|l|l|l|}
\hline \multirow{2}{*}{ Urban Growth } & Correlation Coefficient & Urban Growth & Drug Abuse \\
\cline { 2 - 4 } & Sig. (2-tailed) & 1.000 & $.587^{*}$ \\
\cline { 2 - 4 } & $\mathrm{N}$ &. & .027 \\
\hline \multirow{3}{*}{ Drug Abuse } & Correlation Coefficient & 14 & $.587^{*}$ \\
\cline { 2 - 4 } & Sig. (2-tailed) & .027 & 1.000 \\
\cline { 2 - 4 } & $\mathrm{N}$ & 14 &. \\
\hline Significance & $*$ Correlation is significant at the 0.05 level (two-tailed) \\
\hline
\end{tabular}



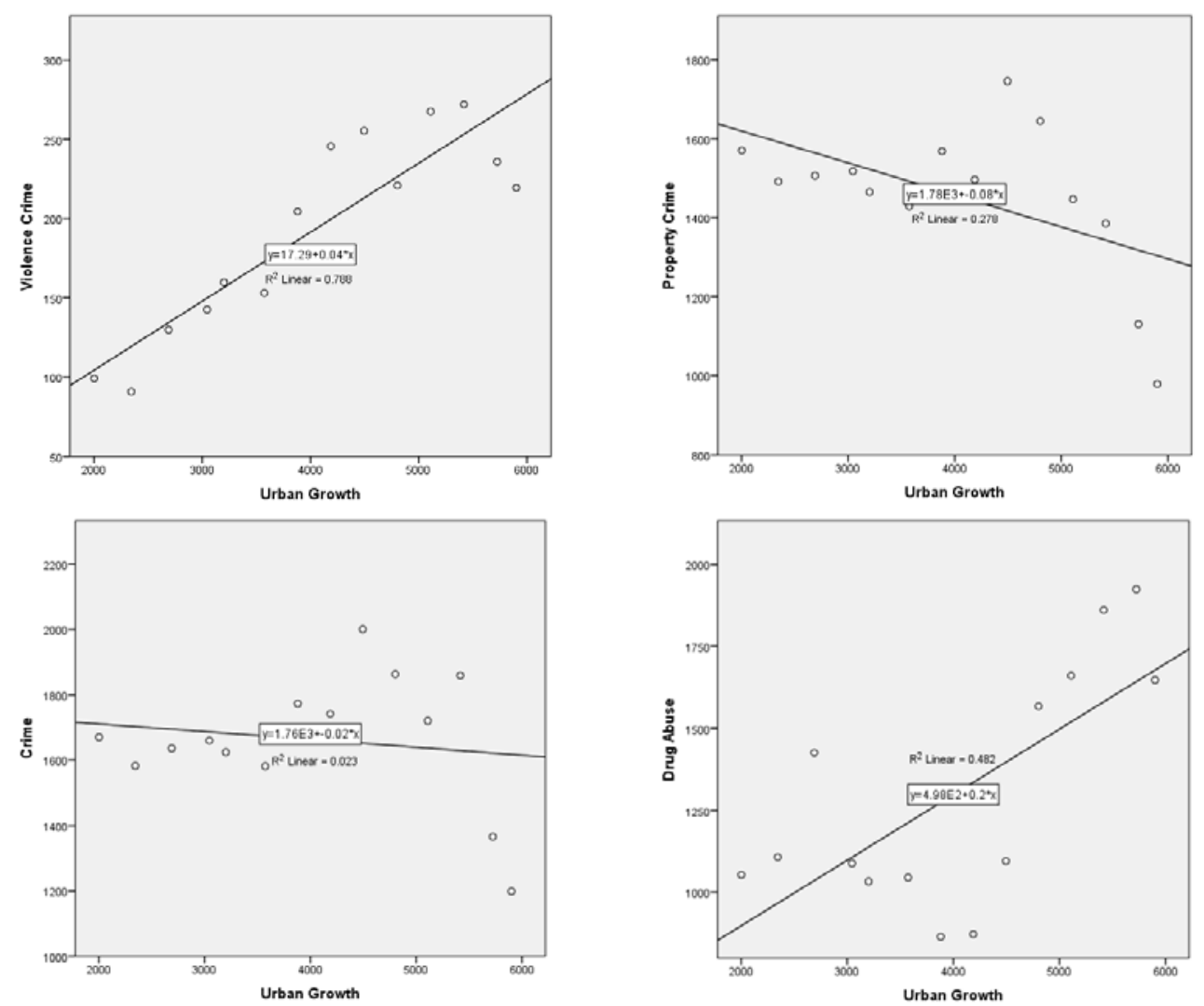

Figure 2: Correlation coefficient between crime, violence crime, property crime, drug abuse and urban growth in Sungai Petani, Kedah.

\subsection{The survey data}

The respondents are categorised into middle class $50 \%$, lower class $33 \%$ and the upper at $18 \%$ in terms of educational, occupation and income level. Their daily problems faced are cost of living, the facilities in their housing area and the rising cost of education of their children. Most of the respondents manage to overcome these daily problems but the Indian community feels a greater life pressure relative to other ethnic groups. Comparing with their parents and grandparents, the respondents do experience a slight vertical social mobility. However, the Indians faced limited social mobility and across generation.

The ethnic boundary of the groups studied is thinned and this would also them to have cross-cutting social ties and relationship with other ethnic groups. Even, governance of the nation is positively responded and with ethnic variations on certain issues pertaining to freedom of speech and job in the public sector to reflect the multi-ethnic population of the nation. Ethnically, again the Indian community feels marginalised relative to other ethnics.

Despite the social disadvantages observed in the studied area, social cohesion prevailed. A minority of the respondents studied feel that there are no social problems and crimes in their community. The Indians and the middle class recorded the highest in declaring the 
prevalence of social problems and crimes in the community. The community members faced social problems through the harassment by the street-bikers, the gangsters and the loafers in the community. In terms of crimes, burglarizing, blackmailing/extortion and stealing motorbikes are the main criminal activities. Despite such views on the situation of the social problems and crimes in Sungai Petani, only an insignificant percentage of them do feel the 'fear of crimes' in their life here. They also feel satisfied with the safety condition in this town.

The respondents argue that religious and ethnic differences were compounded by gangsterism in the society as the cause to ethnic skirmishes in 2012. Feeling of anger and vengeance out of that incident to other ethnic groups are diminishing but feeling of insecure towards others is still prevalent. However, the comfort gains in interacting with other ethnics is still high and the majority of them still desire to continue residing in Sungai Petani. In fact, life in the town of Sungai Petani is peaceful. However, they do hope that the problem of gangsterism, physical infrastructure and social inequality in the community must be managed.

\section{DISCUSSIONS}

The development of the town of Sungai Petani are planned and managed by the local authority of Kuala Muda, Sungai Petani, Kedah. The local Structure Plan adopts give due emphasis to the aspects of societal well-being of the local communities and environmental care. However, there are problems in the local community where the social well-being of the local citizens has not reached the satisfying level. This is proven by the social survey carried. The main results of the present study show that urban growth in Sungai Petani is moderately beneficial to the well-being of the people.

The analysis of the urban development change shows that the urban growth rate has exponential increased from $3.1 \%$ of the development area for the year 2000 to $24.17 \%$ for 2013 in Sungai Petani. Drastic rate of urban development has brought various social ills to the population of the town. Nearly $50 \%$ of the respondents, especially from among the low social status, the B40 and the intergenerational poor agreed that their daily life is facing the social problems identified, with the crime rate yet to reach a gratifying standard and encountering crimes on a weekly basis. These social ills are also compounded by the lack of accessibility to good infrastructure and public facilities in their areas. Specifically, the Indians and the middle class claimed that the social problems in their area are at a worrying concern and the crime issues are getting rampant in the area.

Despite this rapid rate of urban growth of Sungai Petani, marginalisation of the Indian poor and a slight climbing of the social mobility ladder are the core sociological problems identified. These sociological problems not only lead to the observed social problems and crimes in the areas but would also not augur well to developing cross-cutting social ties and relation across ethnic and religious groups among the residents in this town. The fragility of these inter-ethnic relations is thus opened to manipulation, even when the root cause is not in ethnicity and religion itself. This is the underlying explanation to the incident of skirmishes that took place between the Indians and the Malays in 2012 there. Ethnic and religious differences among Malaysians are not the cause to the incident of 2012 but just an effect of bad governance and development failures.

Our findings show a positive association between increase in the urban area and the crime rate for urban growth and violence crime and drug abuse. These social and criminal behaviours if not manage will lead to tension and conflict in a multi ethnic setting as the town of Sungai Petani. With such data collected and explanation given for the social and criminal 
behaviour observed, the governance of the day must give priority to overcoming the imbalance development in the country.

Thus, for future study, the local authority must plan urban development holistically because the expansion of urban development area does have direct impacts on the community. To ensure the inhabitants of the towns to attain a better societal well-being, the urban planning for development must take into account the changing urban land used, its impact on the environment and the society.

\section{CONCLUSION}

Nowadays, urbanization is a global phenomenon. Urbanization is closely related to industrialization. Industrialization is the driving force of the economy in ushering in modernization and modernity into the developing country likes Malaysia. The positive benefits of modernisation are ample but social inequality and marginalisation taking place in the midst of prosperity. This negative sides of development and urbanization have politically destabilised and created ethnic skirmishes among the bottom 40 and the poor in Malaysia. Ethnicity is not the cause to the tension and conflict in the country.

The finding of this research has contributed to knowledge, practice and policy formulations related to urban development and well-being. The knowledge gained based on this research will also be helpful to plan for further urban redevelopment by taking into consideration all the important factors, particularly well-being, to make the city area a better place to live in. The most important contribution is the methodology of this study which combines the capabilities of social sciences and spatial analyst using GIS in observing and explaining the social phenomena studied. This study has shown that combining the disciplines of science and technology with that of the social sciences would be able to strengthen our observation of the society and the power to explain the challenges faced.

Rapid urban growth, industrialization and imbalance development are linked to the social problems, crimes and social conflicts in the town and city areas. The social implications as the GIS, crime and social survey data support this finding as it affects all the communities in the neighborhood and, thus, put a brake to the sustainable development goals planned in the areas.

\section{REFERENCES}

[1] World Bank., Globalisation, Growth and Poverty: Building an inclusive world economy, World Bank: Washington D.C., 2002.

[2] Freedman, M., The Growth of a Plural Society in Malaysia. Pacific Affairs, 33(2): pp. 158-168, 1960.

[3] Swee-Hock, S., The Population of Malaysia, Institute of Southeast Asian Studies: Singapore, 2007.

[4] Clarke, C.G. \& Singh Sidhu, M., Pluralism and segregation in Peninsular Malaysia towns. In Population Dynamics in a Plural Society, Manjit Singh Sindhu and Gavin W Jones (eds). University of Malaya Cooperative Bookshop: Kuala Lumpur, 1981.

[5] Jayasooria, D., Social Development and Indians in Malaysia, Yayasan Strategik Sosial: Kuala Lumpur, 2008.

[6] Department of Statistics, Malaysia, Population of Malaysia. Putrajaya: Department of Statistics, Malaysia, 2017.

[7] Martinussen, J.D., Society, State and Market: a guide to competing theories of development, St. Martin Press: New York, 1997.

[8] World Bank, East Asia's Changing Urban Landscape, Measuring a Decade of Spatial Growth, 2000-2010, World Bank: Washington, D.C., 2015. 
[9] Mansor, M.N. \& Noridayu, M., Relative Strength of Preferences for Association with Coethnics: Malay-Malaysians and Chinese-Malaysians. International Journal of Culture and History, 1(1), 2015.

[10] Kuper, L., Race, Class and Power: Ideology and Revolutionary Change in Plural Societies, Duckworth: London, 1974.

[11] Mansor, M.N., Social Conflicts in Indonesia and Malaysia: Could the Cause be Religious? Journal Kajian Malaysia, 1 \& 2, pp. 188-206, 2000.

[12] Jayasooria, D., Social Development and Indians in Malaysia, Yayasan Strategik Sosial: Kuala Lumpur, 2008.

[13] Mansor, M.N., Nur Suhaili M., \& Nazri M., Impak Insiden Pergaduhan Sungai Petani Ke Atas Kesepaduan Sosial. Perpaduan. Institut Latihan Integrasi Nasional: Putrajaya, 2016 (In Malay Language).

[14] Nur Azura, S., Sufian, A., Bakar, A. \& Nor Fadzlin, M.B., Ke Arah Kedah Maju: Di Antara Perancangan dan Keupayaan, Penerbit Universiti Utara Malaysia: Sintok, 2005 (In Malay Language).

[15] Marzbali, M.H., Abdullah, A., Razak, N.A. \& Tilaki, M.J.M., The influence of crime prevention through environmental design on victimisation and fear of crime. Journal of Environmental Psychology, 32(2), pp. 79-88, 2012.

[16] Taylor, R.B. \& Harrell, A., Physical Environment and Crime, US Department of Justice, Office of Justice Programs, National Institute of Justice, 1996.

[17] Harrison, D., The Sociology of Modernisation and Development, Routledge: London, 2003. 